\begin{tabular}{lcccr} 
T H E & A R C H I V E & O F & M E C H A N I C A L & E N G I N E E R I N G \\
\hline VOL. LVIII & 2011 & Number 2
\end{tabular}

10.2478/v10180-011-0012-8

Key words: identification, parametric models, motion control

\title{
TIME-BASED METHOD FOR THE COMBINED IDENTIFICATION OF VELOCITY-LOOP PARAMETERS
}

\begin{abstract}
Today, a cascaded system of position loop, velocity loop and current loop is standard in industrial motion controllers. The exact knowledge of significant parameters in the loops is the basis for the tuning of the servo controllers. A new method to support the commissioning has been developed. It enables the user to identify the moment of inertia as well as the time constant of the closed current loop simultaneously. The method is based on the auto relay feedback experiment by Aström and Hägglund. The model parameters are automatically adjusted according to the time behaviour of the controlled system. For this purpose, the auto relay feedback experiment is combined with the technique of gradual pole compensation. In comparison to other existing methods, this approach has the advantage that a parametric model for the open velocity loop is derived directly.
\end{abstract}

\section{Introduction}

The identification of controlled systems in servo drives is an important field in controller engineering. The derived models are primarily used for controller tuning. Several tuning algorithms (e.g. symmetrical optimum) have been published, which require exact model parameters as a one main criterion to be efficient. The model order is another important criterion for the accuracy of the tuning rules [1]. According to [7], the velocity controller (PI-Structure) can be tuned based on order-reduced parametric models. The tuning of the velocity controller can be even carried out for oscillatory mechanical systems, because standard velocity controller structures are not able to consider higherorder models.

* Chemnitz University of Technology, Faculty of Mechanical Engineering, Institute for Machine Tools and Production Processes, Reichenhainer Str. 70, Germany; E-mail: stefan.hofmann@mb.tu-chemnitz.de 
In addition, various limitations can be defined in servo drives based on the identified models [2]. In [10] online monitoring functions like detection of variation in the moment of inertia or friction moments have been proposed.

Nowadays, the identification of the velocity controlled system is often carried out in the frequency domain $[12,13]$. However, in the area of low frequencies, the detection of mechanical parameters is restricted, because the measurement is performed in the closed loop. The resulting errors of the magnitude and phase response are estimated in [6]. In addition to the methods that are applied in the frequency domain, standard identification techniques (e.g. step response) in the time domain have been developed [14]. These methods demand high measurement accuracy and are limited, when the expected time constants are in the range of the sample time. The intention of the paper is to establish a new identification method in the time domain, which is suitable for electrical servo drives.

The paper is divided in 5 sections. Subsequent to the introduction, the identification method is discussed theoretically in chapter 2. Chapter 3 describes the experimental set-up. The results of the experiments are presented in chapter 4 . The conclusions are given in chapter 5 .

\section{Identification method}

The relay feedback experiment by Aström and Hägglund [4] is used as an automatic excitation for various plants in the presented identification method. The results are parametric models of the closed current loop $\mathrm{G}_{C u L}$ and of a simplified mechanical system $\mathrm{G}_{\text {mech }}$ which is mainly characterized by the moment of inertia J. A simplified structure of the closed velocity loop is shown in Figure 1 including the velocity controller transfer function $G_{V C}$ and a nonlinear relation of the friction moment $\mathrm{M}_{\text {Fric }}$.

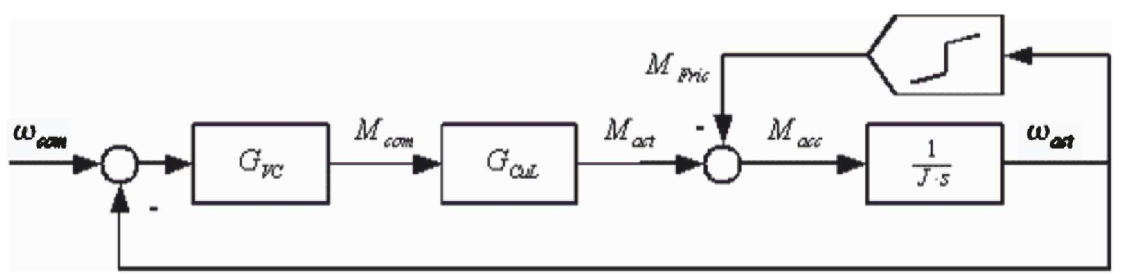

Fig. 1. Structure of velocity loop

For the illustrated closed velocity loop, the effective acceleration torque $\mathbf{M}_{a c c}$ can be described by the difference between the actual drive torque $\mathbf{M}_{a c t}$ and the friction moment:

$$
M_{a c c}=M_{a c t}-M_{F r i c}
$$


In the case the mechanical system is regarded as a single mass system, the angular momentum can be written as:

$$
M_{a c c}=J \cdot \dot{\omega}_{a c t}
$$

Equation 2 can not be applied to identify the moment of inertia, because the acceleration torque $\mathbf{M}_{a c c}$ can not be measured. Consequently, an alternative solution method is required. Therefore, the following approach is proposed.

\subsection{Relay Feedback Parameterization}

The velocity controller $\mathrm{G}_{V C}$ in Figure 1 has to be substituted with a relay with hysteresis $[4,5]$ represented by Equation 5. The friction moment in Equation 1 is not considered. Instead the following approach is applied:

$$
M_{\text {Fric }}=f(\omega)
$$

$\mathbf{M}_{\text {Fric }}$ can be considered as constant at selectable operation points for the command velocity $\omega_{\text {com }}$ :

$$
M_{\text {Fric }}=f\left(\omega_{o p}\right)=\text { const } .
$$

Hence, the relay output $\mathbf{M}_{\text {com }}$ in Figure 2 is defined:

$$
M_{\text {com }}=\left\{\begin{array}{cc}
0 & \omega_{\text {err }} \leq-\omega_{\text {Hyst }} \\
0 ; 2 \cdot M_{\text {Fric }} & -\omega_{\text {Hyst }} \leq \omega_{\text {err }} \leq \omega_{\text {Hyst }} \\
2 \cdot M_{\text {Fric }} & \omega_{\text {Hyst }} \leq \omega_{\text {err }}
\end{array}\right.
$$

In the static case, the acceleration torque yields to:

$$
M_{a c c}= \pm M_{F r i c}
$$

\subsection{Identification of the Closed Current Loop}

For the closed current loop, a first order system plus dead time (FOPDT) is identified by using the relay feedback combined with the method of gradual pole compensation, published in [3,9]. Using this method, the model parameters are automatically adjusted according to the time behaviour of the system (Equation 9). The method is adapted for the identification of the closed current loop as shown in Figure 2.

Considering the model of the closed current loop, given by [2]:

$$
G_{C u L}(s)=\frac{M_{a c t}(s)}{M_{c o m}(s)}=\frac{1}{T_{c u r} \cdot s+1} \cdot e^{-s T_{d}}
$$




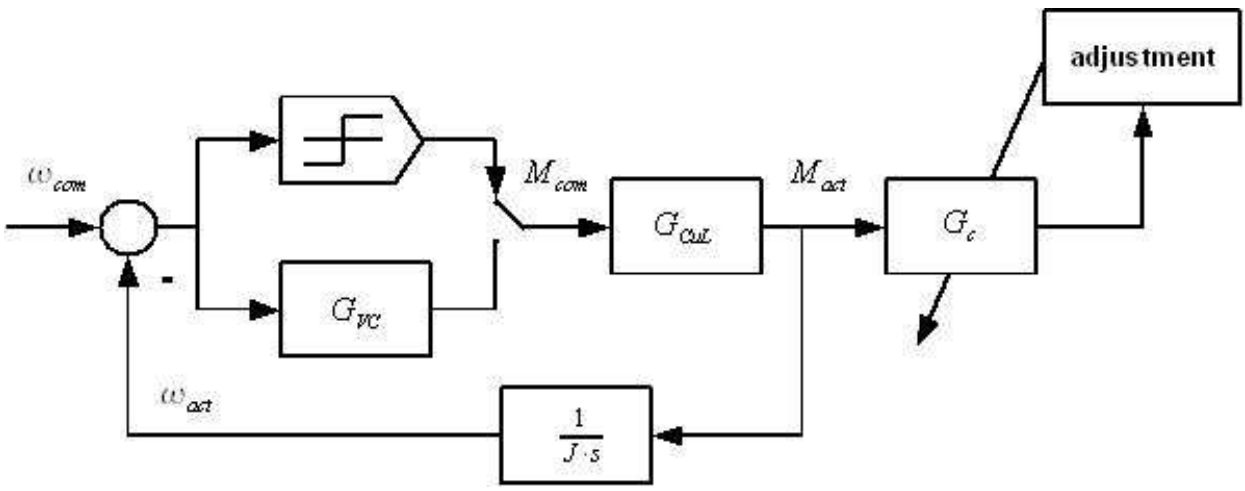

Fig. 2. Identification of closed current loop parameters with gradual pole compensation

The model parameters can be estimated by using the compensator $\mathrm{G}_{c}$ :

$$
G_{c}(s)=\frac{X_{c}(s)}{M_{a c t}(s)}=\frac{T_{c u r}^{*} \cdot s+1}{s}
$$

and the proposed adjustment strategy [9] for the gradual pole compensation (Figure 3).

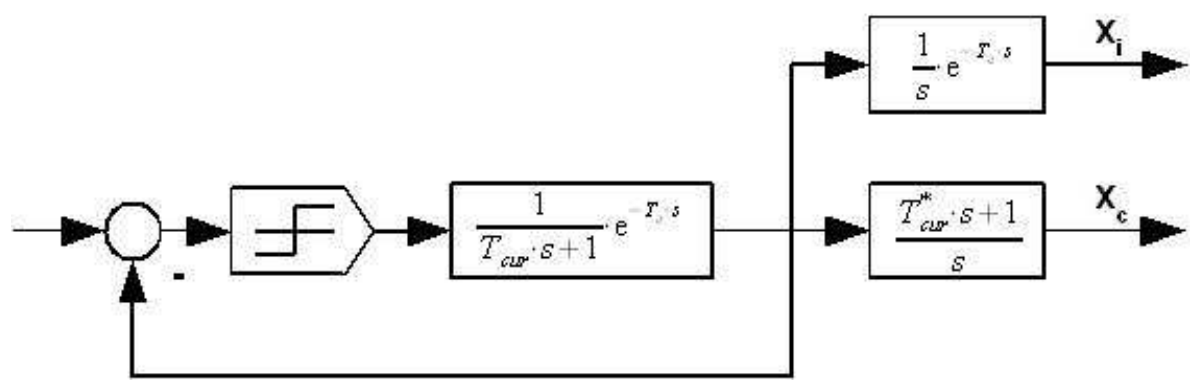

Fig. 3. Criterion for compensator adjustment

The compensator time constant is adjusted according to the magnitude ratio resulting in the following equation.

$$
T_{\operatorname{cur}(n+1)}^{*}=T_{\operatorname{cur}(n)}^{*} \cdot \frac{\hat{x}_{i}}{\hat{x}_{c}}
$$

As Figure 3 illustrates, the performance of the method is based on the powerful criterion. Hence, the criterion has been proven to be very fast and highly efficient. This has also been approved for time constants which are smaller than the sample time of the controller. The dead time of the closed current loop $\left(\mathrm{T}_{d}\right)$ can be determined by the time behaviour of $\mathrm{x}_{c}(\mathrm{t})$ and $\mathrm{M}_{\text {com }}(\mathrm{t})$. The value of the dead time is not required in the presented identification method, as shown in Equation 15. 


\subsection{Identification of the Moment of Inertia}

Achieving the closed current loop model, the identification structure (Figure 4) has to be changed.

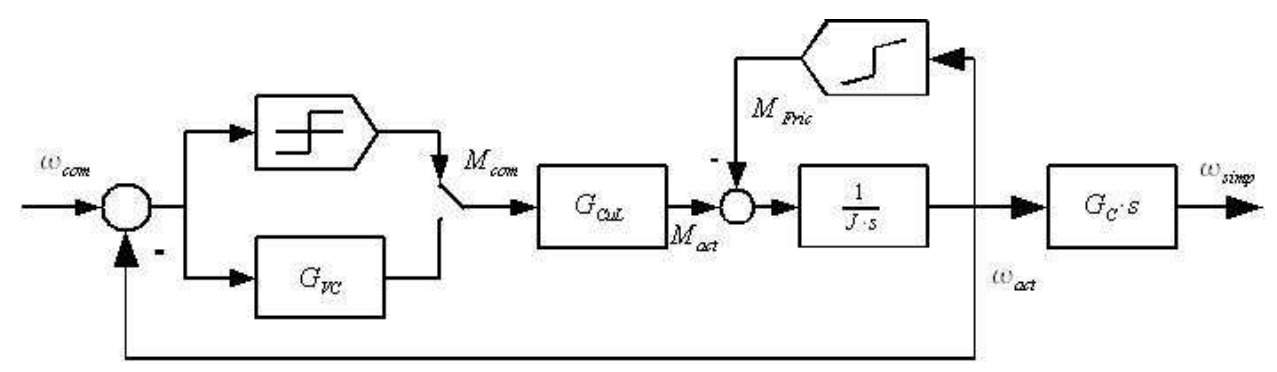

Fig. 4. Structure of the identification of the moment of inertia

Based on the Equations 4-6, the relay output $\mathbf{M}_{\text {com }}$ can be used for calculation. The relation to the actual torque $\mathbf{M}_{a c t}$ has been established by Equation 7. The forward path of the loop becomes:

$$
G_{C u L}(s) \cdot G_{m e c h}(s)=\frac{\omega_{a c t}(s)}{M_{\text {com }}(s)}=\frac{1}{T_{\text {cur }} \cdot s+1} \cdot e^{-s T_{d}} \cdot \frac{1}{J \cdot s}
$$

The influence of the delay on the actual velocity $\omega_{\text {act }}$ can be eliminated by using the compensator (equation 8).

$$
\begin{gathered}
\omega_{\text {simp }}(s)=\omega_{\text {act }}(s) \cdot G_{c}(s) \cdot s \\
\omega_{\text {simp }}(s)=M_{\text {com }}(s) \cdot \frac{1}{\left(T_{\text {cur }} \cdot s+1\right)} \cdot e^{-s T_{d}} \cdot \frac{1}{J \cdot s} \cdot \frac{T_{\text {cur }}^{*} \cdot s+1}{1}
\end{gathered}
$$

In the case of $T_{\text {cur }}^{*}=T_{\text {cur }}$ :

$$
\omega_{\text {Simp }}(s)=M_{\text {com }}(s) \cdot \frac{1}{J \cdot s} \cdot e^{-s T_{d}}
$$

The further derivation is carried out in the time domain. Especially, the time behaviour of $\omega_{\text {simp }}$ is of interest:

$$
L^{-1}\left\{\omega_{\text {Simp }}(s)\right\}=L^{-1}\left\{\frac{M_{\text {com }}(s)}{s} \cdot \frac{1}{J} \cdot e^{-s T_{d}}\right\}
$$

The dead time does not have to be considered, because only the magnitude ratio is significant.

$$
\omega_{\text {simp }}(t)=\frac{1}{J} \cdot \int M_{\text {com }} \cdot d t
$$


The closed loop with relay controller (Figure 4) achieves oscillation with the time period $\left(\mathrm{T}_{P e r}\right)$. The oscillation at the operation point can be expressed as a sum for the sampled system.

$$
\omega_{\text {simp }}(t)=\frac{1}{J} \cdot\left[\sum_{t=0}^{\frac{T_{P e r}}{2}} M_{\text {com }} \cdot t-\sum_{t=\frac{T_{P e r}}{2}}^{T_{P e r}} M_{\text {com }} \cdot t\right]
$$

The structure, shown in Figure 3, is used for the calculation of the moment of inertia. A half-cycle is sufficient for the magnitude of $\omega_{\text {simp }}$. Finally, the resulting formula is:

$$
J=\frac{M_{\text {com }} \cdot T_{P e r}}{2 \cdot \hat{\omega}_{\text {simp }}}
$$

\section{Experimental set-up}

The presented approach has been verified on an experimental rig, as shown in Figure 5. It is equipped with the SIEMENS motion controller SIMOTION D445 and SINAMICS drives. The motion controller is sampled with $500 \mu$ s and the drive components with $125 \mu$ s. There are two mechanical configurations (System $1 \&$ System 2).

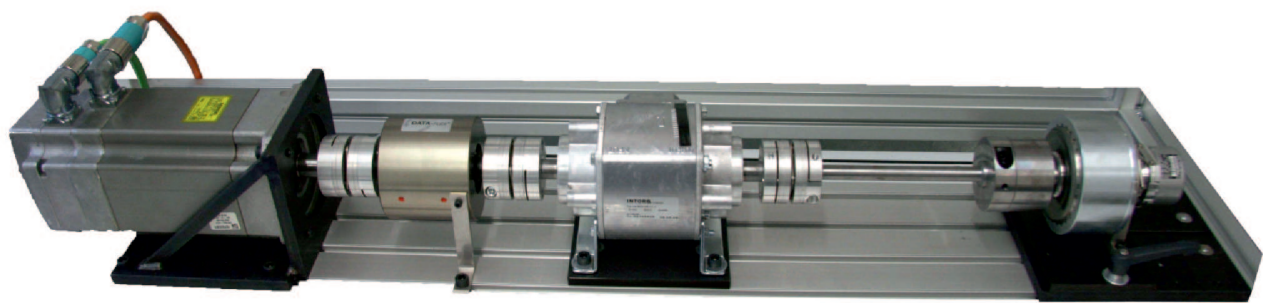

Fig. 5. Experimental rig variable moments of inertia

The experimental set-up contains of a two-mass-system and a threemass-system, whereas the third mass can be connected by a clutch. The basic parameters are the moment of inertia $J$, the resonance frequency $f_{0}$ and antiresonance frequency $\mathrm{f}_{N}$. The preset values of the parameters for the experimental set-up are shown in Table 1.

For the application of the tuning rules and the monitoring functions, which are the aim of the identification, order-reduced parametric models are sufficient. Consequently, it is not necessary to take a two or three mass system as basis for the mechanical system. A single-mass-system satisfies the requirements for the identification. Therefore, only moment of inertia (Equation 18) is of interest for the calculation. 
Table 1.

Characterization of test rig with variable moment of inertia

\begin{tabular}{|c|c|c|c|}
\hline Test rig configuration & $J$ & $f_{0}$ & $f_{N}$ \\
& $K g m^{2}$ & $H z$
\end{tabular}

\section{Results}

The closed current loop (Equation 7) under relay feedback and the identified model are shown in the following time plot. Figure 6 shows the time behaviour of the relay output $\mathbf{M}_{c o m}$ and the actual torque $\mathbf{M}_{a c c}$. In addition, the identified model is included. Although the identified model has been calculated in a higher sample time (500 $\mu \mathrm{s})$ then the measurement of the actual torque has been carried out in the drive $(125 \mu \mathrm{s})$. The reaction curves are nearly identical. Hence, the performance of the chosen adjustment strategy is proven.

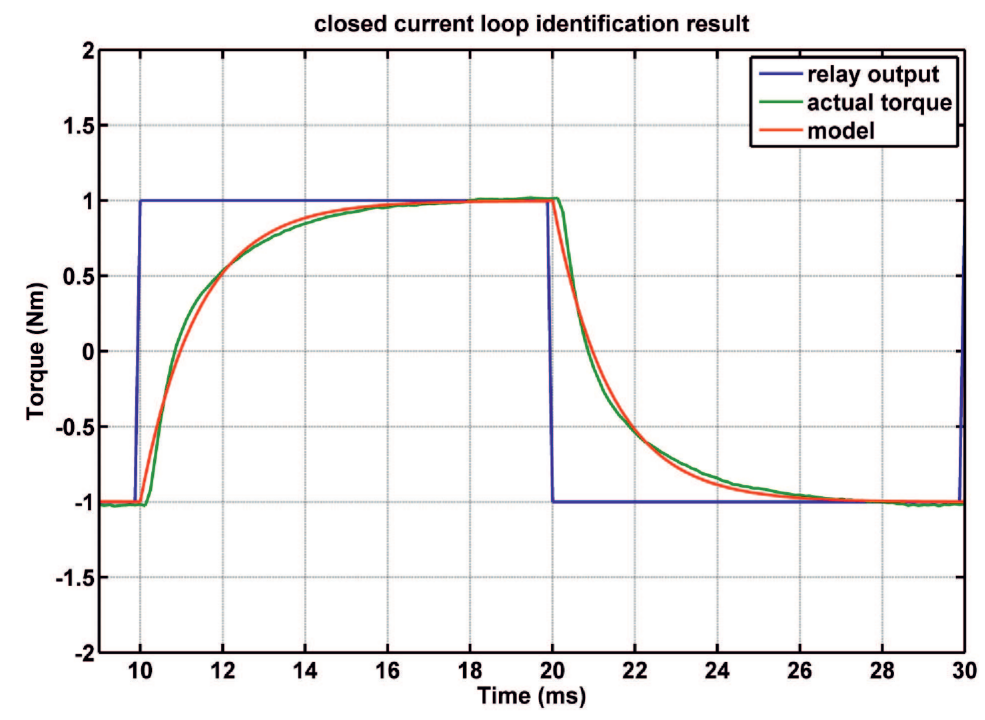

Fig. 6. Time behaviour of the closed current loop

According to Equation 5, the hysteresis of the relay is a free selectable parameter. Therefore, a compromise between the magnitude of the relay oscillation and the linearization error for the friction moment (Equation 4) has to be found. 
The moment of inertia for the two-mass-system as well as the threemass-system at different operation points are plotted against the hysteresis (Figure 7, Figure 8). The hysteresis is displayed in percent of the velocity.

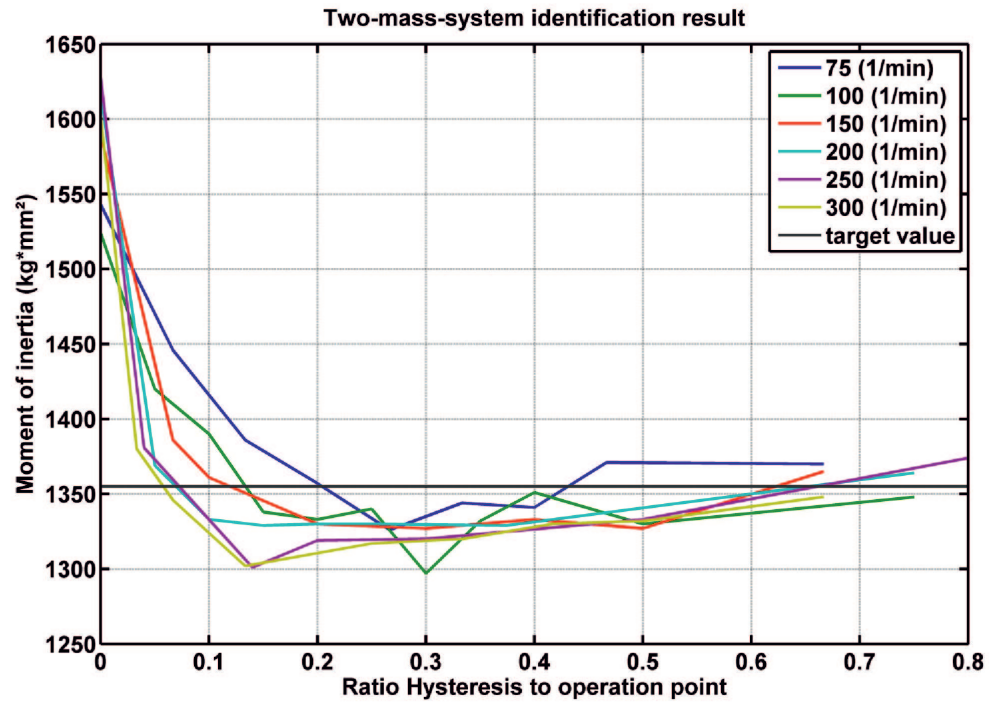

Fig. 7. Results of the moment of inertia (System 1)

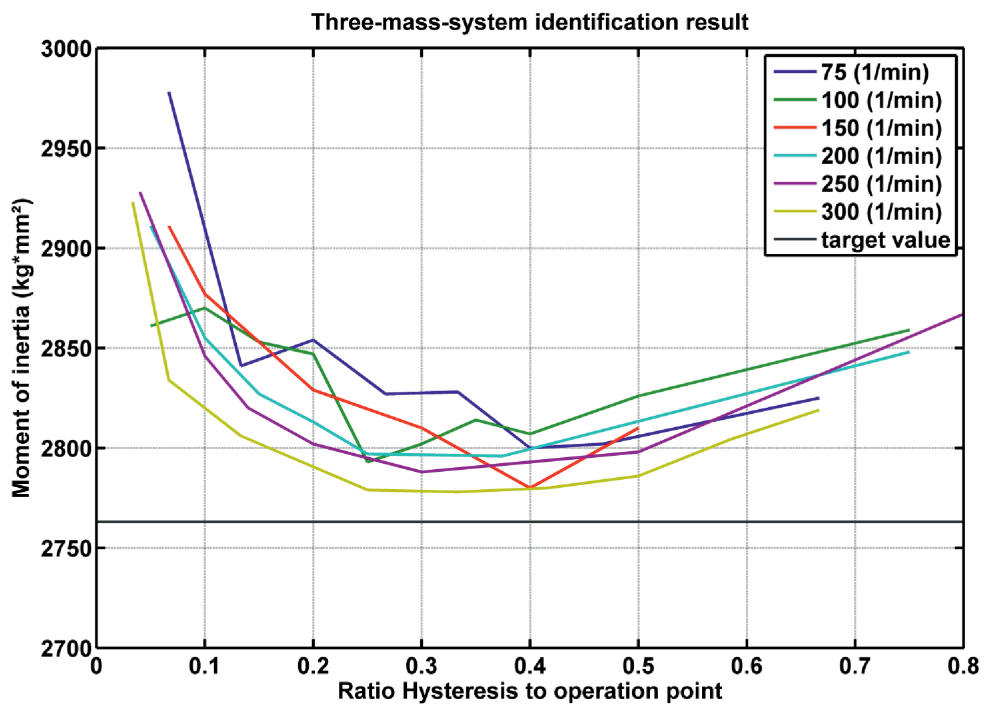

Fig. 8. Results of the moment of inertia (System 2) 
The graphs in the diagrams demonstrate that the value of the moment of inertia for the two-mass-system und the three-mass-system can be identified with sufficient accuracy. A variance of less than $4 \%$ can be achieved by setting the hysteresis to $5 \%$ for the two-mass-system and to $15 \%$ for the three-mass-system. Comparing the achieved moments of inertia to other investigations $[8,11]$, the experiments have shown an improvement in the accuracy. Simultaneously, a small value of the velocity (operation point) is sufficient.

\section{Conclusion}

In this paper, a new method for the combined identification of significant parameters in the time domain has been presented. As an excitation, the auto relay feedback experiment has been used and has been combined with the gradual pole compensation. The model parameters are identified by applying a powerful criterion. A higher accuracy of the model parameters has been achieved. The advantages of the approach are: requirement for less a priori knowledge, the simultaneous identification of various parameters and low excitation of the mechanical system.

The presented algorithm has successfully been implemented as an automatic tool in the motion control system SIMOTION. Based on the results of the combined identification, the focus of future research is set to the parameterization of the velocity controller.

Manuscript received by Editorial Board, December 29, 2010;

final version, February 24, 2011.

\section{REFERENCES}

[1] Schroeder D.: Elektrische Antriebe - Regelung von Antriebssystemen, Springer 2001.

[2] Gross H., Hamann J., Wiegärtner G.: Elektrische Vorschubantriebe in der Automatisierungstechnik, Publicis Corporate Publishing 2006.

[3] Reinisch K.: Analyse und Synthese kontinuierlicher Steuerungs- und Regelungssysteme, Verlag Technik, 1996.

[4] Åström K. J., Hägglund T.: Advanced PID Control, ISA, 2006.

[5] Johnson M. A., Moradi M. H.: PID Control New Identification and Design Methods, pp. 311319, Springer, 2005.

[6] Schuette F.: Automatisierte Reglerinbetriebnahme für elektrische Antriebe mit schwingungsfähiger Mechanik, Dissertation Thesis, Shaker Verlag 2003.

[7] Zirn O.: Machine Tool Analysis - Modelling, Simulation and Control of Machine Tool Manipulators, Habilitation Thesis ETH Zuerich 2008.

[8] Burkhardt H.: Applikation von Algorithmen zur Bestimmung von Massenträgheitsmomenten im Umfeld industrieller Bewegungssteuerungen, Diploma Thesis, Chemnitz University of Technology 2010. 
[9] Hofmann S., Hellmich A., Schlegel H.: Identification of parametric models for commissioning servo drives. In: Brezina T., Jablonski R.(Editors): Recent Advantages in Mechatronics 20082009, pp. 287-292, Springer 2009.

[10] Schoenherr R., Quellmalz J., Schlegel H.: Ueberwachung und Bewertung von Antriebsregelungen bei Verzicht auf zusätzliche Sensorik, VDI-Kongress AUTOMATION 2010, Baden-Baden 2010.

[11] Hellmich A., Hofmann S., Schlegel H.: Non-invasive parameter identification by using the least squares method, $6^{\text {th }}$ International Conference Mechatronics Systems and Materials, Opole 2010.

[12] Wertz H., et al.: Computer aided commissioning of speed and position control for electrical drives with identification of mechanical load, Industry Applications Conference (IEEE) 1999.

[13] Beineke S., et al.: Comparison of parameter identification schemes for self-commissioning drive control of nonlinear two-mass systems, Industry Applications Conference (IEEE) 1997.

[14] Mink F; Baehr A; Beineke S.: Self-commissioning feedforward control for industrial servo drive, Advanced Electromechanical Motion Systems \& Electric Drives Joint Symposium (IEEE) 2009.

\section{Metoda złożonej identyfikacji parametrów pętli sterowania prędkością wykorzystującą właściwości czasowe}

\section{Streszczenie}

We współczesnych przemysłowych układach sterowania ruchem standardowo wykorzystuje się kaskadowe systemy z pętlą sterowania położeniem, prędkością i pętlą prądową. Dokładna znajomość istotnych parametrów pętli jest podstawą dla optymalizacji działania serworegulatorów. Autorzy opracowali nową metodę wspomagającą pozyskiwanie tych danych. Umożliwia ona jednoczesną identyfikację momentu bezwładności i stałej czasu w zamkniętej pętli prądowej. Metoda jest oparta na eksperymencie Åströma and Hägglunda z automatycznym przekaźnikowym sprzężeniem zwrotnym. Parametry modelu są dobierane automatycznie, biorąc pod uwagę właściwości sterowanego systemu $\mathrm{w}$ dziedzinie czasu. Wykorzystano $\mathrm{w}$ tym celu eksperyment $\mathrm{z}$ automatycznym przekaźnikowym sprzężeniem zwrotnym w połączeniu $\mathrm{z}$ techniką stopniowej kompensacji biegunów. W porównaniu do innych istniejących metod, zaletą takiego podejścia jest możliwość bezpośredniego wyznaczenia modelu parametrycznego dla otwartej pętli sterowania prędkością. 